\title{
Application of the MSAP Technique to Evaluate Epigenetic Changes in Plant Conservation
}

\author{
María Elena González-Benito ${ }^{1}\left(\mathbb{D}\right.$, Miguel Ángel Ibáñez ${ }^{2}$ (D) Michela Pirredda ${ }^{1}$, Sara Mira ${ }^{1}$ (i) \\ and Carmen Martín 1,*(i) \\ 1 Departamento de Biotecnología-Biología Vegetal, Escuela Técnica Superior de Ingeniería Agronómica, \\ Alimentaria y de Biosistemas, Universidad Politécnica de Madrid, Av. Puerta de Hierro, $\mathrm{n}^{\mathrm{o}} 2-4$, \\ 28040 Madrid, Spain; me.gonzalezbenito@upm.es (M.E.G.-B.); michela.pirredda@upm.es (M.P.); \\ sara.mira@upm.es (S.M.) \\ 2 Departamento de Economía Agraria, Estadística y Gestión de Empresas, Escuela Técnica Superior de \\ Ingeniería Agronómica, Alimentaria y de Biosistemas, Universidad Politécnica de Madrid, \\ Av. Puerta de Hierro, n² 2-4, 28040 Madrid, Spain; miguel.ibanez@upm.es \\ * Correspondence: mariacarmen.martin@upm.es
}

Received: 22 August 2020; Accepted: 8 October 2020; Published: 10 October 2020

\begin{abstract}
Epigenetic variation, and particularly DNA methylation, is involved in plasticity and responses to changes in the environment. Conservation biology studies have focused on the measurement of this variation to establish demographic parameters, diversity levels and population structure to design the appropriate conservation strategies. However, in ex situ conservation approaches, the main objective is to guarantee the characteristics of the conserved material (phenotype and epi-genetic). We review the use of the Methylation Sensitive Amplified Polymorphism (MSAP) technique to detect changes in the DNA methylation patterns of plant material conserved by the main ex situ plant conservation methods: seed banks, in vitro slow growth and cryopreservation. Comparison of DNA methylation patterns before and after conservation is a useful tool to check the fidelity of the regenerated plants, and, at the same time, may be related with other genetic variations that might appear during the conservation process (i.e., somaclonal variation). Analyses of MSAP profiles can be useful in the management of ex situ plant conservation but differs in the approach used in the in situ conservation. Likewise, an easy-to-use methodology is necessary for a rapid interpretation of data, in order to be readily implemented by conservation managers.
\end{abstract}

Keywords: cryopreservation; DNA methylation; multinomial model; plant tissue culture; seed storage

\section{Epigenetic Variation in Ex Situ Plant Conservation: The Role of DNA Methylation Changes}

Human activity in recent centuries, and particularly in recent decades, has led to overexploitation and a significant degradation of habitats, with a consequent loss of natural populations and even species. More recently, pollution and climate change have contributed to biodiversity loss [1,2]. This genetic erosion has also affected crop genetic resources due to modern agricultural practices and the introduction of new varieties, with higher yield, which have displaced traditional landraces [3]. From the 1950s, projects on germplasm conservation have been developed to guarantee biodiversity and stop genetic erosion.

The most appropriate method to conserve whole ecosystems and their biodiversity is in situ conservation, i.e., in their natural habitat. However, this approach is not always possible, and in these cases ex situ conservation (the conservation of individuals outside their natural habitats) is the best option [2]. The most frequent plant ex situ conservation method is seed banking, mainly by maintaining orthodox seed samples at low temperature and water content. Orthodox seeds are characterized by 
their ability to tolerate desiccation (generally at $10 \%$ water content or lower) and to retain their viability during long-term storage in the dry state and at low temperature (generally $-20^{\circ} \mathrm{C}$ ), reaching a glassy state during which their cellular activities and metabolism are extremely reduced $[4,5]$. This method can guarantee the biodiversity conservation of a high number of species in the long term and at a low cost. However, this technique is not feasible for those species with recalcitrant seeds (not tolerant to reduction of their water content and to low temperature), with asexual reproduction (e.g., hybrid species) or with high heterozygosity [6]. For these types of germplasm, in vitro conservation (slow growth) techniques and cryopreservation are successful options. Besides, another ex situ conservation procedure for plant material difficult to preserve is field collection, which has been mainly used for crop species. However, this approach requires large areas of land, is labor intensive and plants are exposed to environment changes and plagues [7].

The main target of biological conservation is to retain high levels of biodiversity. In the case of ex situ conservation, samples must represent the diversity of the natural population and of the species to be maintained. In the last years, conservation biology studies have focused on the measurement of this variation to establish demographic parameters, diversity levels and population structure in order to design the appropriate conservation strategies [8].

Ex situ conservation must face a double role; on the one hand, it must be representative of the diversity of the population of origin, and at the same time it must ensure the maintenance of the characteristics of the conserved genotypes. Although these techniques contribute to plant biodiversity maintenance, they present some problems that need to be solved in order to improve conservation efforts [3]. Seed banks, slow-growth and cryopreservation are the main ex situ conservation techniques that can guarantee a higher control of the samples compared to field collections. Environmental conditions for these approaches may cause an important stress to the conserved plant material. Low temperature is a common factor for these techniques, which could be from a slight reduction in the case of in vitro slow-growth $\left(5-10^{\circ} \mathrm{C}\right)$, to a severe reduction (near $-180{ }^{\circ} \mathrm{C}$ ) in the case of cryopreservation. Additionally, water content reduction is usually applied in seed banking and cryopreservation; light intensity reduction besides starvation is used in most of the slow-growth protocols.

Species can respond to new environmental situations through molecular and phenotypic changes [9]; similarly, individuals under ex vitro conservation conditions can undergo modifications to face the new conditions. In the last few years, many studies have focused on the potential role of epigenetic mechanisms in the short and long-term adaptation of species to the changing environment $[10,11]$. Epigenetic changes are related to changes in the genome (histone modifications, DNA methylation and siRNA), without affecting the DNA sequence.

Among the different epigenetic mechanisms, DNA methylation, and particularly cytosine methylation is the most studied one in plants. A methyl group is transferred to a cytosine residue, forming C5-methylcytosine $\left(5-{ }^{\mathrm{m}} \mathrm{C}\right)$ [12]. The enzymes that catalyze this reaction are known as DNA Methyltransferases (DNMTs), and they have primarily two general classes of enzymatic activities: de novo methylation and maintenance of methylation. De novo methyltransferases newly methylate cytosines and are mainly expressed in early embryo development. Maintenance methyltransferases act throughout the life of the organism to maintain the methylation pattern that has been established by the de novo methyltransferases. In plants, de novo methylation is carried out by Domains Rearranged Methyltransferase 2 (DRM2), a DNMT3 homolog, while maintenance methylation is catalyzed by three different processes: CG methylation by DNA methyltransferase 1 (MET1), the plant homolog of DNMT1; CHG methylation by Chromomethylase 2 (CMT2) and CMT3, plant specific DNA methyltransferases; and asymmetric $\mathrm{CHH}$ methylation through persistent de novo methylation by CMT2 and RNA-directed DNA methylation (RdDM) [13,14]. However, the pathways controlling the establishment and maintenance of DNA methylation in plants, as well as those involved in the removal of DNA methylation, are less characterized than in mammals [15]. 
The importance of cytosine methylation relies on the fact that it has been associated with numerous biological processes, such as genomic imprinting, transcriptional regulation of genes and transposable elements and gene silencing [13,16-18]. Besides, DNA methylation is considered sensitive to the environment and is involved in the plasticity and adaptative responses to changing environments [19]. Modifications of DNA methylation patterns can appear as a response of changing environments, producing "environmentally induced phenotype variation", but may also arise spontaneously as "stochastic phenotype variation" $[19,20]$. Although epigenetic modifications can be reset between generations [21], some of them, especially those involving DNA methylation, may not be reset, resulting in a transgenerational stability of these markers [11]. In addition, the stability of epimutations over generations is expected to be higher in plants than in animals [22].

All these considerations make ex situ conservation an especially sensitive scenario in which it is important to control the state of epigenetic markers such as DNA methylation. The stressful conservation conditions may induce epigenetic changes to face new environmental situations. However, this mechanism, that in natural populations acts as an adaptive tool, may cause changes that could affect the phenotype, which would endanger the maintenance of the characteristics of the conserved plants. In the conservation context, epigenetic changes take on a greater dimension if we consider that many studies relate them with genetic mutations [23]. Jiang et al. [24] found higher frequency of mutations and epimutations (changes in cytosine methylation status) in Arabidopsis thaliana under salinity stress. However, although authors reported a considerable increase of both types of variation, they did not explain a possible connection between them.

An additional problem arises when tissue culture (based on clonal propagation) is used for conservation, since epigenetic reprogramming mechanisms that are associated with meiosis can be bypassed in asexual reproduction, which could promote the build-up of epigenetic variation in vegetatively propagated plants [25].

\section{Methylation Sensitive Amplified Polymorphism (MSAP) Technique among Other Techniques to Detect DNA Methylation Changes}

There are numerous available procedures to screen DNA methylation, that have been thoroughly described. The most common techniques for analyzing DNA methylation are those based on methylation-sensitive restriction enzymes or on bisulfite modification [26].

Bisulfite sequencing is one of the main techniques used for analyzing methylation of DNA due to its high definition, since it produces results with single-nucleotide resolution [27]. Genomic DNA is treated with sodium bisulfite, provoking the deamination of unmethylated cytosines, which results in their conversion to uracil while methylated cytosines remain stable. Subsequently, bisulfite-treated DNA is amplified by PCR using specific primers, and uracil residues are replaced by thymine. Amplification fragments are sequenced allowing the identification of methylated cytosines. This technique is also suitable for genome-wide analyses. Bisulfite treatment generates high resolution outcomes, but its high cost, time and intensive labor are some of its main limitations, especially in genome-wide analyses of DNA methylation [27]. Additionally, there is a risk of incomplete conversion of unmethylated cytosines to uracil [28] or DNA degradation via depurination because of the high temperatures and bisulfite concentrations used in the process [29].

Other techniques are based on the use of restriction enzymes with different sensitivity to methylation such as the combination of MspI and HpaII isoschizomers. These restriction enzymes are used in Methylation Sensitive Amplified Polymorphism (MSAP) technique and differentially cleave their recognition site $5^{\prime}$-CCGG-3' based on methylation differences of cytosine residues.

The MSAP approach was first described by Reyna-Lopez et al. [30] in a study on fungi and later modified for its use in plant species by Xiong et al. [31]. Ever since, the method has been adopted in more than 100 publications, focusing mainly on developmental biology (e.g., [32,33]), hybridization and polyploidization (e.g., [34]), plant breeding (e.g., [35]) and plant response under stress conditions [36-38]. 
More recently MSAP analyses also became an important tool to answer questions in the emerging field of "ecological epigenetics", studying epigenetic processes in an ecological context [19].

MSAP is fundamentally a modification of the Amplified Fragment Length Polymorphism (AFLP) method based on the digestion of genomic DNA with methylation-sensitive restriction endonucleases followed by the amplification of digested fragments. In the MSAP protocol, the extracted genomic DNA is divided into two aliquots, each digested with EcoRI, which recognizes the GAATTC target site and is thought to be negligibly influenced by DNA cytosine methylation ("indifferent cutter"). The aliquots are then digested with the methylation-sensitive MspI or HpaII isoschizomers, respectively ("methyl-sensitive cutter"), which recognize the same restriction site (CCGG) but show differential sensitivity to cytosine methylation. The DNA samples digested with EcoRI and MspI or with EcoRI and HpaII are ligated to two dsDNA adapters compatible with EcoRI and MspI/HpaII-generated ends. Subsequently, ligated fragments are pre-amplified using non-selective or pre-selective primers complementary to the adapters followed by amplification with a pair of selective primers (these are oneto three-base extended variants of non-selective or pre-selective primers at $3^{\prime}$ ends). Such amplification produces a reduced population of fragments that are separated in order to compare the respective band patterns $[39,40]$.

It is important to mention that although HpaII and MspI recognize the same motif (5'-CCGG-3'), literature is inconsistent regarding their cleaving activity in different methylation contexts (e.g., [41-43]). According to Schulz et al. [39], and following the methylation sensitivity criteria of the restriction enzyme database REBASE [44], HpaII only recognizes sites that are hemi-methylated at the external cytosine ( ${ }^{\mathrm{m} C C G G)}$, while MspI only recognizes sites being hemi- or fully methylated at the internal cytosine ( $\left.\mathrm{C}^{\mathrm{m}} \mathrm{CGG}\right)$. None of the enzymes cut at the recognition site when it is fully methylated at the external cytosine, or hemi- or fully methylated at both, internal and external, cytosine residues. However, when there is no methylation in CCGG-sequences, both enzymes can digest [39]. For each sample there are two sets of amplification data (one from each restriction enzyme). The binary information for each fragment (present/absent) reveals its methylation status.

One of the main advantages of this technique in the plant conservation context is that MSAP allows for research on non-model systems, even if their genome is not sequenced, as the amplification of restriction fragments is independent on the availability of genome sequence information [40].

Technically, MSAP is similar to AFLP, a procedure that has been well documented over the years; both techniques require the same equipment, similar protocols and expertise. Furthermore, this method is cost-effective, with minimal start-up and ease to scale-up, as the same reagents can be used on multiple taxa [45]. In addition, it generates powerful data to detect differences among populations or treatments, as it can screen a large number of individuals at multiple loci concurrently. These characteristics make this technique very versatile, resulting effective in a wide variety of studies focused on different biology aspects, such as ecology, plasticity, preservation or evolution.

On the other hand, the main shortcoming of MSAP is that it screens anonymous loci [45]: it cannot specify the region or gene influenced by methylation because the sequence adjacent to each locus remains unknown. A candidate solution for this drawback could be the extraction and sequencing of the fragments obtained and the database search for homologous sequences to those fragments (BLAST). It is important to mention that the extraction of MSAP bands is extremely laborious, because of the small band size and the large number of bands obtained. In the analyses of MSAP results, it is complicated to establish a relationship between methylation and phenotype, as there is not always an explicit connection between DNA methylation and gene-expression. This issue could possibly be assessed by performing association mapping to link phenotype to epigenetic states at particular loci [46]. Likewise, it must be considered that MSAP results in a dominant banding pattern and, therefore, it is not possible to distinguish heterozygote epigenotypes. There is a further technical shortcoming regarding the MSAP procedure: the banding pattern observed when both MspI and HpaII fail to cut. Such conditions can be generated by both genetic (point mutation to the restriction site, 
or changes to adjacent restriction sites) and epigenetic (hypermethylation, methylation of all cytosines in the restriction site) causes. Thus, some methylated states may remain undetected.

Among other techniques based on methylation-sensitive restriction enzymes, methylation-sensitive amplified fragment length polymorphism (metAFLP) can be mentioned. This technique is also a modification of the AFLP technique, but it uses different endonucleases to those used in MSAP. Acc65I and KpnI are isoschizomers, which differ in their sensitivity to template methylation, and, together with MseI are used for the initial digestion of genomic DNA [47].

\section{Seed Conservation}

Ex situ conserved seeds, even if the most optimal storage conditions are used, are subjected to ageing and this results in the loss of valuable genetic diversity. To avoid genetic loss over time, seed accessions are regenerated; nevertheless, this represents an expensive procedure and could lead to the genetic drift of the accession by selection, contamination, presence of mutations or human error [48]. There are over four million seed accessions worldwide in germplasm banks nowadays [49], approximately two thirds in long term storage. The genetic and epigenetic stability of all that stored biodiversity is, therefore, of the upmost importance.

Seed ageing has been described as the loss of seed quality overtime. Several physiological and biochemical changes have been associated with seed ageing: reactive oxygen species (ROS) accumulation, lipid peroxidation, membrane phospholipids loss, decrease in the activity of antioxidant enzymes [50,51], impaired protein synthesis, protein inactivation, changes in enzyme activities, protein hydrolysis, and post-translational modifications [48,52], among others. ROS interact with cellular biomolecules, and can cause serious oxidative damage to proteins, nucleic acids and lipids $[53,54]$. Furthermore, some of the by-products of lipid peroxidation, such as the aldehydes malondialdehyde (MDA) and 4-hydroxy-2-nonenal (4-HNE), are highly reactive [55]. Both molecules have been shown to interact with proteins (leading to loss of function) and DNA (leading to mutations) or inhibit DNA and protein synthesis $[53,56]$. Besides, epigenetic regulation, in particular DNA methylation, has been proposed as a possible indicator of seed ageing [57] as it has been related to viability loss during seed storage as the following reported studies show.

MSAP has been scarcely used to reveal the methylation status of stored seeds (Table 1). Pirredda et al. [58] studied non-stored and stored rye (Secale cereal L.) seeds at different stages of ageing, as well as the seedlings obtained from them. Seeds were stored at $35{ }^{\circ} \mathrm{C}$ and $15 \%$ water content fresh weight basis (wc. fwb.), under vacuum or air atmosphere. DNA methylation-related changes (15-30\% both de novo methylation and demethylation) were detected in the stored seeds compared to control seeds. These variations were not associated with storage time, even when germination was significantly reduced with time $(25 \%$ and $80 \%$ of germination reduction after 13 and 29 days, respectively). However, DNA methylation-related changes significantly increased with storage time in the seedlings obtained from the stored seeds: from $13 \%$ after 13 days to $23-27 \%$ after 29 days. In this study, the effect of storage conditions (time and atmosphere) on the methylation status in stored seeds and seedlings was analyzed by a multinomial logistic regression model. In Mentha aquatica L. [59], the DNA methylation changes detected increased from $8 \%$ in stored seeds (compared to control seeds) to $16 \%$ in the seedlings produced from them, compared to those obtained from control seeds.

Despite the scarcity of studies using MSAP technique, methylation status in stored or desiccated seeds and, in some cases also in the derived seedlings, has been studied with other methods, such as two-dimensional thin-layer chromatography (TLC). In TLC, ${ }^{\mathrm{m}} \mathrm{C}$ and other nucleotides are labelled with $\left[{ }^{32} \mathrm{P}\right]$ ATP and T4 polynucleotide kinase; the amount of global ${ }^{\mathrm{m}} \mathrm{C}$ is calculated as a spot intensity ratio [60]. The TLC technique has been used combined with MSAP in vernalization studies [61]. By means of TLC, it was observed that in the common pear (Pyrus communis L.) the global level of DNA methylation decreased in seeds with very low water content $(2.8 \%$ wc. fwb.) compared to $8.8 \%$ wc. (control seeds); desiccation also produced a slight germination decrease [62]. Similarly, 3-month old seedlings obtained from dried seeds showed lower DNA methylation than seedling 
from control seeds. In another work of the same group, DNA methylation of Acer platanoides L. seeds (orthodox), increased when they were desiccated from $51 \%$ wc. fwb. to $15 \%$ [63]. However, when further desiccation was imposed (9-6\% wc.) the methylation level decreased, together with germination and seedling emergence, especially in the seed lots collected at higher moisture content ( $51 \%$ vs. $21 \%$ wc. fwb.). Even though P. communis and A. platanoides seeds are classified as orthodox, they seem to differ in their tolerance to extreme desiccation. Furthermore, these authors also compared the methylation levels of embryonic axis and cotyledons from two species of the same genus, but with different storage behavior. In embryonic axes of both A. platanoides (orthodox) and A. pseudoplatanus $\mathrm{L}$. (recalcitrant) lower methylation DNA levels were observed as the water content decreased; however, this effect was only found in the cotyledons of A. pseudoplatanus [64]. These results indicate that desiccation-induced changes in total DNA methylation are both tissue- and seed category-specific. Moreover, the methylation levels of 3-month old seedlings derived from seeds at different water contents were similar among them, except for A. platanoides seedlings from severely desiccated seeds ( $3.5 \%$ wc.), despite the germination decrease observed in all desiccated samples.

Orthodox seeds can also be stored in liquid nitrogen without the need of pretreatments. The percentage of methylated DNA has been studied in cryopreserved maize (Zea mays L.) kernels and seedlings generated from them [65]. DNA methylation was determined by MSAP although no statistical analysis was performed. The percentage of DNA methylation was similar in cryopreserved and non-cryopreserved kernels ( $72 \%$ vs. 65\%). In 5-day old seedlings, shoots derived from non-cryopreserved seeds showed higher methylation levels than those from cryopreserved seeds, while the opposite was observed in roots. As seedling growth proceeded (9-day old seedlings), DNA methylation in shoots from cryopreserved seeds increased, while it decreased in seedlings from non-cryopreserved kernels. Those differences in the methylation status of seedlings could be related to a slight growth delay observed in those obtained from cryopreserved seeds.

By means of metAFLP, no differences were found in the methylation level of 2-week old rye plants derived from seeds stored for 25 years either under conventional seed banking or cryopreserved, although cryopreserved seeds showed higher percentage of normal germination [66].

\section{In Vitro Plant Conservation}

The main strategy for in vitro conservation is "slow growth", which is achieved by modifying environmental conditions and/or medium composition with the aim of limiting plant metabolism and growth. This approach is mainly used for short- or medium-term conservation. The growth limitation allows prolonging subculture intervals without significantly affecting the viability of the explants [67].

Temperature reduction is the most widely applied modification, which can be combined with a decrease in light availability (low radiation or short photoperiod), or even darkness. Another common limitation is the reduction of macro- and micro-nutrients of the medium, sometimes combined with a decrease in sucrose concentration. Modifications of the medium osmotic potential are also used to reduce the water availability (e.g., addition of mannitol or sorbitol). The use of plant growth retardants is another strategy, although less frequent [67-70].

Slow growth has been applied in the last few years to many species, mainly for medium-term conservation, including diverse crops [69], ornamental plants [70] and endangered species [71].

Since the stressful conditions imposed by tissue culture procedures, and their implications on the epi-genetic stability of cultured material, are well known [72,73], many studies using molecular markers have been carried out to examine the genetic stability of in vitro conserved cultures [74-76]. However, the number of studies focused on the DNA methylation-related stability of slow-growth cultures is scarce (Table 1).

The first study on DNA methylation of plants recovered from slow-growth was performed by Harding [77] in potato (Solanum tuberosum L.) using a technique based on the use of isoschizomers $\mathrm{HpaII} / \mathrm{MspI}$ and other restriction enzymes, but different to MSAP. In this work, morphological changes and hypermethylation of genomic DNA were detected in plants conserved in a medium supplemented 
with mannitol. The author attributed methylation changes to a possible adaptive response to high stress osmotic conditions.

The MSAP technique was used by Hao and Deng [78] in apple (Malus pumila Mill.) shoot tips conserved for one year at $4{ }^{\circ} \mathrm{C}$ and a photoperiod of $12 \mathrm{~h}$, with a medium supplemented with $2 \%$ mannitol. Using AFLP markers no genetic variation was detected between the conserved samples and the shoot prior to storage (control). However, 6 out of 389 analyzed markers changed in the MSAP study. These changes were not attributed by authors to de novo methylation, nor to demethylation, but to changes from hemi-methylation to full methylation status. The variation of the DNA methylation status was considered a response of the plants to different stresses associated with in vitro conservation conditions. Despite the significant variation detected, the authors justified the use of this conservation technique as an advantage over field collections.

Not only shoots are subjected to in vitro conservation, other explants, such as callus, have been stored for medium-term, usually associated to breeding programs, as in the case of Citrus callus [79]. The previously mentioned research group, working with callus of grapefruit, analyzed the epi-genetic stability of callus stored in slow-growth conditions for one year (Table 1). Genetic stability was assessed by Random Amplified Polymorphic DNA (RAPD) markers and ploidy level, and no significant differences were found. However, the MSAP analysis revealed one variation (among 308 markers analyzed) attributed to a demethylation event.

In studies on the use of slow growth in hop (Humulus lupulus L.) germplasm collections, Peredo et al. $[80,81]$ found changes in the DNA methylation status of the in vitro plants conserved for one year at $4{ }^{\circ} \mathrm{C}$ and $12 \mathrm{~h}$ photoperiod (Table 1 ) when compared with greenhouse control plants. The response of the three genotypes analyzed varied, but changes were detected $(11.2-18.3 \%$ of the analyzed markers) in all of them, corresponding mainly to demethylation events (4-11\% of the detected changes, depending on the genotype). As in the previous mentioned works, genetic analysis was done using RAPD and AFLP markers, and similarly to those studies no genetic variation was detected. For these authors, the explanation of the DNA methylation changes observed laid on the procedures used in the in vitro culture, while conservation conditions per se had a minor effect. This conclusion was drawn from the comparison with cryopreservation results, which also have an in vitro common protocol (see next section).

Slow growth storage has been used more recently in the conservation of synthetic seeds of diverse species [82-84], applying a reduction in the conservation temperature. Although in some cases the genetic stability was assessed using molecular markers or flow cytometry [82,84], the DNA methylation status was not analyzed.

The lack of studies about the DNA methylation-related status of plants from slow growth storage does not mean that this technique is not being applied nowadays, as there are over fifty thousand accessions stored in vitro [49]. Although the technique is widely employed in germplasm banks and conservation institutions, analyses are not frequent enough. Furthermore, when stability studies have been carried out, they have focused primarily on genetic stability, as for example the use of Simple Sequence Repeat (SSR) markers in the analysis of conserved artichoke (Cynara cardunculus L.) [85], Inter Simple Sequence Repeat (ISSR) markers in tomato (Solanum lycopersicum L.) [86] and RAPD together with flow cytometry in slow growth of Taraxacum [87].

The scarce works published in this area showed significant changes in the DNA methylation status of the conserved plants although genetic changes have not been detected. However, methylation changes can produce phenotypic variations affecting the true-to-type identity of the conserved material. Likewise, it is well known that these changes may be involved in the activation of transposable elements and may also affect cytogenetic stability [88].

Harding [77] and Peredo et al. [80,81] attributed the DNA methylation changes detected in slow growth to the in vitro culture procedures. Studies of the effect of tissue culture on the DNA methylation stability have detected significant changes, as for example the work of Gimenez et al. [89], on in vitro propagated garlic, a species usually conserved in germplasm banks through slow growth storage. 
These authors, using MSAP, detected changes, mainly demethylations, in plants under prolonged in vitro culture. These findings support the need to evaluate the DNA methylation status of the conserved material, mainly considering that the core objective of this procedure is to maintain the integrity and functionality of samples [85]. Techniques as MSAP may be a useful tool to analyze plants obtained from slow growth conservation. In addition, a deeper study on the effect of conservation conditions on stability (temperature, light, added substances, etc.) could result in a better development of conservation techniques in order to obtain high quality conserved plants according to integrity values. Sequential analyses have been carried out in other conservation techniques such as cryopreservation (see next section), and similar studies could help to understand the slow growth process and its implications in DNA methylation.

\section{Cryopreservation}

Plant cryopreservation allows for the long-term storage of valuable germplasm otherwise difficult to preserve. Cryopreservation is the storage of live cells, tissues or organs at temperatures below $-150{ }^{\circ} \mathrm{C}$, which ensures an extremely low metabolism, allowing long-term storage. As mentioned before, these techniques have special importance when conserving diversity of plants with recalcitrant seeds, short-lived seeds or vegetatively propagated [55,90-92]. Worldwide there are over 700,000 cryopreserved accessions of crop species representing $13.12 \%$ of the total number preserved in germplasm banks [49]. Besides, cryopreservation is often considered as the only effective method to prevent cell ageing and reduce the risks of culture loss caused by contamination or technical errors when preserving in vitro cultures of undifferentiated somatic plant cells [93], used as a source of phytochemicals for food and pharmaceutical industries.

In order to avoid ice crystal formation and/or desiccation damage in cells, two main types of cryopreservation techniques have been developed $[6,94]$. Some are based on a controlled decrease of temperature and the use of cryoprotectants, forming extracellular ice crystals and causing the cells to dehydrate to the point where they would turn to a glass (vitrify). The second type is based on the vitrification of both extra- and intracellular solutions, by the concentration of solutions and their fast cooling, without undergoing crystallization. Among these techniques are the ones based on the use of vitrification solutions (vitrification sensu stricto) and those based on encapsulation-dehydration. In most cryopreservation protocols, using any of these techniques or their modifications, plant cells, tissues or organs are generally preconditioned/pretreated by, for example, in vitro culture on medium with high sucrose concentration or containing other cryoprotective substances, or by incubation at low temperature. The relationship between cryopreservation and in vitro culture is, therefore, very close as often the plant vegetative material used in cryopreservation is obtained and recovered in in vitro culture, and pretreatments are applied also in vitro. The papers reviewed in this section refer to studies on cryopreservation of in vitro plant material.

The treatments imposed on cells to avoid intracellular ice formation or extreme dehydration produce stresses at the cellular level that, although they may not lead to cellular death, could produce alterations in biomolecules [55]. Damages to cells have been related to the toxicity of cryoprotectants, cell membrane integrity alteration, mitochondria disruption, or oxidative stress $[55,95]$. Oxidative stress constitutes a major component of cryo-injury, caused primarily by ROS $[95,96]$. Each of the steps in the cryopreservation protocol presents the possibility of oxidative damage, due to physical damage (excision) and the osmotic stress involved in the process, as many studies have shown [97].

As has been mentioned before (see Section 4), the stressful conditions of in vitro culture could account for the epigenetic changes observed after cryopreservation [98]. Nevertheless, changes in DNA cytosine methyltransferase expression and changes in histone acetylation or methylation have been reported after cryopreservation of bovine embryos and mouse and pig oocytes, respectively [99].

Although a considerable amount of literature has been published on plant genetic stability after cryopreservation [2,100-102], the effect that this process has on epigenetic stability has been scarcely approached. MSAP is one of the techniques most widely used for DNA methylation-related studies 
of plant material after cryopreservation. Other employed methods are amplified DNA methylation polymorphism (AMP [103]) and metAFLP [104]. Johnston et al. [105] studied total DNA methylation by high-performance liquid chromatography (HPLC).

Most of the studies in which MSAP were used to evaluate DNA methylation changes after cryopreservation showed that demethylation events were the most frequent, when compared to the non-cryopreserved control plant material (Table 1).

Hao et al. [106] studied the genetic and DNA methylation stability of apple (M. pumila) in vitro shoot tips after cryopreservation by encapsulation-dehydration. While no changes were observed in genetic markers (AFLP), MSAP showed five demethylation events in cryopreserved shoot tips when compared to non-cryopreserved ones out of the 380 bands observed. The authors hypothesized that the change in the DNA methylation status could have been related to the observed enhancement of root capacity after cryopreservation, as DNA demethylation/methylation in plants play an important role in regulating plant development and organ or tissue differentiation [107]. Hao et al. [108] also found similar results after the cryopreservation of strawberry (Fragaria vesca L.) shoot apices, again by encapsulation-dehydration, although this time the frequency of demethylation events was lower: 1 out of 314 bands. An increase in demethylation events after cryopreservation compared to in vitro control plant material has also been reported using vitrification-based protocols. Citrus callus showed 1 de novo methylation and 3 demethylation sites, out of approximately 358 markers [109].

Potato shoot tips, derived form in vitro plants, were cryopreserved by the DMSO-droplet method and stored for 7 years, while another group of in vitro plants were maintained for the same period with periodical subculture [110]. The methylation status of cryopreservation-derived shoots and shoots maintained in vitro were compared in three random biological samples selected from both groups. The changes in the methylation events were low $(0.9 \%)$, most of them being demethylation events $(0.6 \%)$. However, there were cases in which the biological repetitions for the same treatment differed; most of the changes (3.4\%) were demethylation events in particular cryopreserved samples [110].

Zhang et al. [111] compared the DNA methylation status of kiwi (Actinidia chinensis Planch.) plants originated from cryopreserved (by vitrification) apices to those from in vitro multiplication. Plants were studied at two developmental stages after recovery: after 8 weeks of in vitro culture after cryopreservation or after further 3 months acclimation in the greenhouse. In the cryopreserved derived plants, more changes (compared to the in vitro counterparts) were observed in in vitro than in acclimatized plants, which could indicate transient changes: 52 methylation changes vs. 7, out of 718-701 bands. In the in vitro grown plants 30 of the 52 changes were demethylation events and 22 de novo methylation events.

Adu-Gyamfi et al. [98] compared, by MSAP analysis, cocoa (Theobroma cacao L.) somatic embryos, multiplied by in vitro culture or cryopreserved and subsequently multiplied, with the tree from which the starting material for the embryogenesis was obtained. They did not consider if the methylation changes obtained were demethylation or de novo methylation. However, they found an increase in DNA methylation-related variability in all in vitro and cryopreserved samples, especially in the latter. The DNA methylation-related distance (calculated using Analysis of Molecular Variance inferred from the analysis of epiloci) to the donor plant of the cryopreserved and subsequently cultured embryos was 0.65 and that of the in vitro maintained embryos 0.48 . The authors had found in previous works phenotypic variability in cryopreserved cocoa somatic embryos but little genetic instability; therefore, they hypothesized that those phenotypic variations may be due to DNA methylation changes.

The DNA methylation-related status of three hop cultivars after in vitro cold storage or cryopreservation was compared to potted greenhouse-grown plants [80]. The cold stored shoots were initiated in vitro and stored at $4{ }^{\circ} \mathrm{C}$ for a year. The shoots originated from slow-cooling cryopreserved apices, stored in liquid nitrogen for three years, were recovered and grown in vitro for further 4 months. Both treatments shared a common step of $1-2$ weeks of cold acclimation at $-1{ }^{\circ} \mathrm{C}$ and $16-\mathrm{h}$ dark $/ 22{ }^{\circ} \mathrm{C}$ 8-h light. The percentages of methylation events changes were $35.7 \%$ and $36.73 \%$, respectively, for coldand cryo-stored plants; $63.61 \%$ of those changes were shared by both treatments. For both treatments, 
approximately $47 \%$ of changes were due to demethylation. The high proportion of common changes could be explained by the in vitro growth of both types of plant material as they were compared to potted plants, or by the common cold acclimation step.

The discussion of the methylation changes observed after cryopreservation is somehow complex due to the different developmental stages at which the DNA of the treated and the control samples is extracted (Figure 1). DNA methylation level varies among different plant tissues and also at different developmental stages [107]. The comparison of plant material at different developmental/physiological stages will generate differences in the methylation pattern without discerning if those changes are due to the treatments applied or to the plant stage.

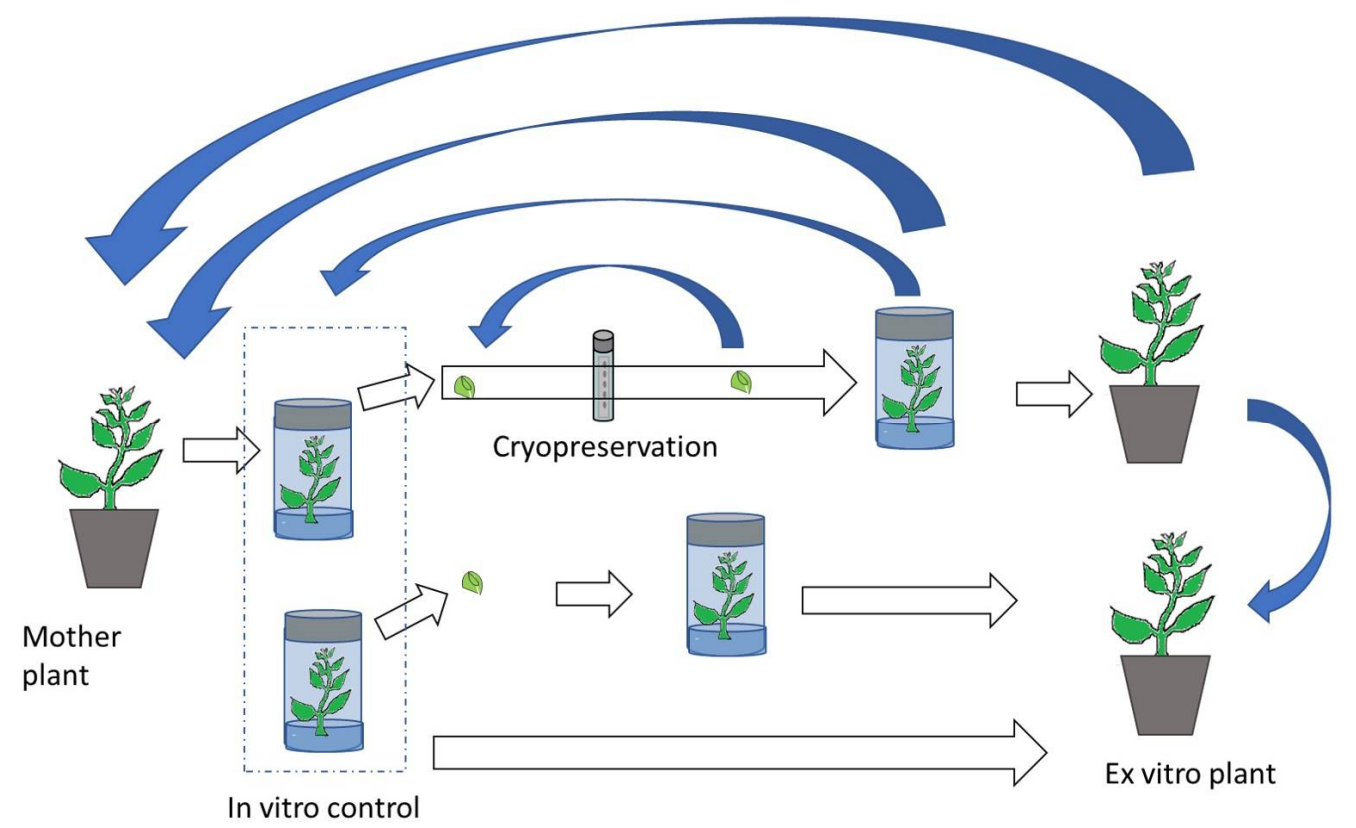

Figure 1. Possible comparisons established after in vitro or cryopreservation protocols for DNA methylation studies to check the fidelity of conserved plants. White arrows: culture process. Blue arrows: comparisons between stages.

Ibáñez et al. [112] studied the methylation changes in mint (Mentha $\times$ piperita L.) shoot apices just after each step of the cryopreservation protocol by encapsulation-dehydration, without further in vitro growth. This allowed them to determine the accumulated effects of each treatment applied. The control sample consisted of apices from in vitro cultured shoots. The percentages of methylation changes increased significantly along the protocol compared to control apices (step " $\mathrm{A}$ " in Figure 2): from $35 \%$ after the cold acclimation treatment $(\mathrm{N})$ to $53 \%$ in apices recovered from liquid nitrogen (LN). Contrary to previous works on methylation changes after cryopreservation, the most frequent events were de novo methylation (59\% after LN step). However, after one-day in vitro recovery ( $\mathrm{LNr}$ ), the methylation changes reverted to only a $40.8 \%$, therefore becoming more similar to control apices. 


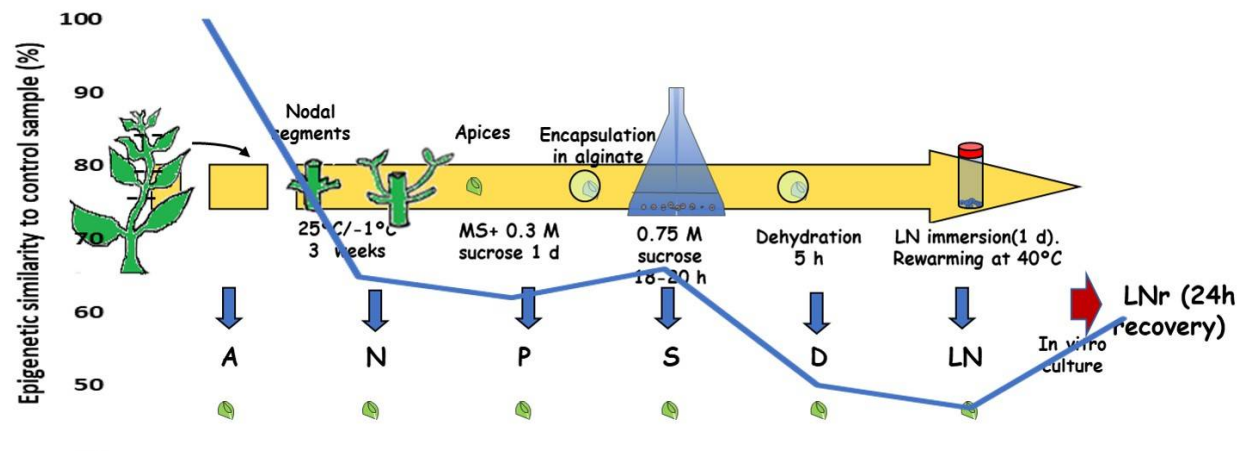

Figure 2. Steps of the cryopreservation protocol at which the methylation status of mint apices was studied in Ibáñez et al. [112]: control (A), cold acclimation (N), preculture in sucrose (P), alginate beads in sucrose (S), dehydration (D), immersion in liquid nitrogen (LN), immersion in liquid nitrogen and one day recovery ( $\mathrm{LNr}$ ). Curve represents the percentage of DNA methylation similarity to the control sample.

Table 1. Studies of DNA methylation stability of conserved plant germplasm using Methylation Sensitive Amplified Polymorphism (MSAP) markers. Wc.: water content; fwb.: Fresh weight basis; $\sqrt{ }$ : genetic stability reported; NA: study not carried out; SE: somatic embryos.

\begin{tabular}{|c|c|c|c|c|c|c|}
\hline Species & Studied Organ & Control & $\begin{array}{l}\text { Conservation } \\
\text { Technique }\end{array}$ & $\begin{array}{l}\text { Genetic } \\
\text { Stability }\end{array}$ & $\begin{array}{c}\text { Detected DNA } \\
\text { Methylation } \\
\text { Variability }\end{array}$ & Ref. \\
\hline \multicolumn{7}{|c|}{ Seed conservation } \\
\hline Zea mays & Caryopsis & $\begin{array}{l}\text { Non- } \\
\text { cryopreserved } \\
\text { caryopsis }\end{array}$ & $\begin{array}{l}\text { Caryopsis stored } \\
12 \% \text { wc. fwb. and } \\
\text { storage in liquid } \\
\text { nitrogen for } 1 \text { year }\end{array}$ & NA & $\begin{array}{l}\text { Increase in the DNA } \\
\text { methylation } \\
\text { percentage from } 65.2 \% \\
\text { to } 72.6 \%\end{array}$ & [65] \\
\hline Secale cereale & $\begin{array}{l}\text { Embryo and } \\
\text { seedlings }\end{array}$ & $\begin{array}{l}\text { Embryos and } \\
\text { seedlings from } \\
\text { non-stored } \\
\text { caryopsis }\end{array}$ & $\begin{array}{c}\text { Caryopsis stored } \\
35^{\circ} \mathrm{C} \text { and } 15 \% \text { wc. } \\
\text { fwb. stored for } 13 \text { or } \\
29 \text { days }\end{array}$ & $\begin{array}{l}\sqrt{ } \text { RAPD in } \\
\text { embryos, } 5 \% \\
\text { changes in } \\
\text { seedlings }\end{array}$ & $\begin{array}{c}15-30 \% \text { DNA } \\
\text { methylation changes } \\
\text { in seeds; } 13-27 \% \text { in } \\
\text { seedlings }\end{array}$ & [58] \\
\hline $\begin{array}{l}\text { Mentha } \\
\text { aquatica }\end{array}$ & $\begin{array}{l}\text { Seeds and } \\
\text { seedlings }\end{array}$ & $\begin{array}{l}\text { Non-stored } \\
\text { seeds, and } \\
\text { seedlings from } \\
\text { non-stored } \\
\text { seeds }\end{array}$ & $\begin{array}{l}\text { Seeds stored at } \\
35^{\circ} \mathrm{C} \text { and } 12 \% \text { wc. } \\
\text { for } 28 \text { days }\end{array}$ & $\begin{array}{l}\sqrt{ } \text { RAPD in } \\
\text { seeds; } 13 \% \text { in } \\
\text { seedlings }\end{array}$ & $\begin{array}{l}8 \% \text { DNA methylation } \\
\text { changes in seeds, } 16 \% \\
\text { in seedlings }\end{array}$ & [59] \\
\hline \multicolumn{7}{|c|}{ In vitro slow growth } \\
\hline $\begin{array}{l}\text { Malus pumila } \\
\text { cv. Gala }\end{array}$ & $\begin{array}{l}\text { In vitro shoots, } \\
\text { from single bud }\end{array}$ & $\begin{array}{l}\text { In vitro buds; } \\
\text { state of } \\
\text { development } \\
\text { not stated }\end{array}$ & $\begin{array}{c}\text { Half-strength } \\
\text { medium, sucrose } \\
\text { reduction, } 2 \% \\
\text { mannitol, } 4{ }^{\circ} \mathrm{C}, 12 \mathrm{~h} \\
\text { photoperiod, for } \\
1 \text { year } \\
\text { Half-strength }\end{array}$ & $\sqrt{ }$ AFLP & $\begin{array}{l}6 \text { changed markers } \\
\text { out of } 389 \text { (changes } \\
\text { from DNA } \\
\text { hemi-methylation to } \\
\text { full methylation } \\
\text { status) }\end{array}$ & [78] \\
\hline $\begin{array}{l}\text { Citrus paradise } \\
\text { cv. Red Marsh }\end{array}$ & $\begin{array}{l}\text { Embryogenic } \\
\text { callus }\end{array}$ & $\begin{array}{l}\text { Embryogenic } \\
\text { callus }\end{array}$ & $\begin{array}{l}\text { medium, sucrose } \\
\text { reduction, } 10{ }^{\circ} \mathrm{C} \text {, } \\
\text { darkness, } \\
\text { for } 1 \text { year }\end{array}$ & $\sqrt{ }$ RAPD & $\begin{array}{l}1 \text { DNA demethylation } \\
\text { marker out of } 314\end{array}$ & [79] \\
\hline $\begin{array}{l}\text { Humulus } \\
\text { lupulus }\end{array}$ & $\begin{array}{l}\text { In vitro shoot } \\
\text { cultures }\end{array}$ & $\begin{array}{l}\text { Greenhouse } \\
\text { plants }\end{array}$ & $\begin{array}{c}4^{\circ} \mathrm{C}, 12 \mathrm{~h} \\
\text { photoperiod, for } \\
1 \text { year }\end{array}$ & $\begin{array}{l}\sqrt{ } \text { RAPD, } \\
\text { AFLP }\end{array}$ & $\begin{array}{c}35.7 \% \text { loci changed, of } \\
\text { which } 4-11 \% \text { DNA } \\
\text { demethylation }\end{array}$ & {$[80,81]$} \\
\hline
\end{tabular}


Table 1. Cont.

\begin{tabular}{|c|c|c|c|c|c|c|}
\hline Species & Studied Organ & Control & $\begin{array}{l}\text { Conservation } \\
\text { Technique }\end{array}$ & $\begin{array}{l}\text { Genetic } \\
\text { Stability }\end{array}$ & $\begin{array}{l}\text { Detected DNA } \\
\text { Methylation } \\
\text { Variability }\end{array}$ & Ref. \\
\hline \multicolumn{7}{|c|}{ Cryopreservation } \\
\hline $\begin{array}{c}\text { Malus } \\
\text { pumila cv. M26 }\end{array}$ & $\begin{array}{l}\text { In vitro shoots } \\
\text { from } \\
\text { cryopreser-ved } \\
\text { apices, from } \\
\text { single bud }\end{array}$ & $\begin{array}{l}\text { In vitro buds; } \\
\text { state of } \\
\text { development } \\
\text { not stated }\end{array}$ & $\begin{array}{l}\text { Encapsulation- } \\
\text {-Dehydration }\end{array}$ & $\sqrt{ }$ AFLP & $\begin{array}{l}5 \text { DNA demethylation } \\
\text { markers out of } 380\end{array}$ & [106] \\
\hline Fragaria vesca & $\begin{array}{l}\text { In vitro shoots } \\
\text { from } \\
\text { cryopreser-ved } \\
\text { apices, from } \\
\text { single bud }\end{array}$ & In vitro shoots & $\begin{array}{l}\text { Encapsulation- } \\
\text { Dehydration }\end{array}$ & $\sqrt{ }$ AFLP & $\begin{array}{l}1 \text { DNA demethylation } \\
\text { markers out of } 314\end{array}$ & [108] \\
\hline Citrus & $\begin{array}{l}\text { Callus after } \\
\text { cryopreser-vation, } \\
\text { single cell line }\end{array}$ & Callus & Vitrification PVS2 & $\sqrt{ }$ RAPD & $\begin{array}{c}1 \text { DNA de novo } \\
\text { methylation, } 3 \text { DNA } \\
\text { demethylation } \\
\text { markers, out of } 358\end{array}$ & [109] \\
\hline $\begin{array}{l}\text { Humulus } \\
\text { lupulus }\end{array}$ & $\begin{array}{l}\text { In vitro shoot } \\
\text { form } \\
\text { cryopreser-ved } \\
\text { apices }\end{array}$ & $\begin{array}{l}\text { Greenhouse } \\
\text { plants }\end{array}$ & Slow cooling & $\begin{array}{l}\sqrt{ } \text { RAPD, } \\
\text { AFLP }\end{array}$ & $\begin{array}{c}36.73 \% \text { loci } \\
\text { polymorphic, of } \\
\text { which aprox } 47 \% \\
\text { DNA demethylation }\end{array}$ & [80] \\
\hline $\begin{array}{l}\text { Solanum } \\
\text { tuberosum }\end{array}$ & $\begin{array}{l}\text { In vitro plants } \\
\text { from } \\
\text { cryopreser-ved } \\
\text { shoot tips }\end{array}$ & In vitro plants & $\begin{array}{l}\text { DMSO-droplet } \\
\text { method }\end{array}$ & NA & $\begin{array}{l}3 \text { DNA demethylation } \\
\text { and } 1 \text { DNA de novo } \\
\text { methylation markers } \\
\text { out of } 469\end{array}$ & [110] \\
\hline $\begin{array}{l}\text { Theobroma } \\
\text { cacao }\end{array}$ & $\begin{array}{c}\text { SE (cryo + } \\
\text { in vitro SE) }\end{array}$ & $\begin{array}{l}\text { Leave from } \\
\text { ortet tree }\end{array}$ & Vitrification & NA & $\begin{array}{c}\text { DNA } \\
\text { methylation-related } \\
\text { distances of } 0.5 \\
\text { (similar to those of } \\
\text { in vitro SE) } \\
53 \% \text { DNA }\end{array}$ & [98] \\
\hline $\begin{array}{l}\text { Menthax } \\
\text { piperita }\end{array}$ & $\begin{array}{l}\text { In vitro shoot } \\
\text { apices after each } \\
\text { step of the } \\
\text { protocol }\end{array}$ & $\begin{array}{l}\text { In vitro shoot } \\
\text { apices }\end{array}$ & $\begin{array}{l}\text { Encapsulation- } \\
\text { dehydration }\end{array}$ & $\begin{array}{l}\sqrt{ } \text { AFLP, } \\
\text { RAPD }\end{array}$ & $\begin{array}{c}\text { methylation changes } \\
\text { were observed (being } \\
59 \% \text { de novo } \\
\text { methylation), which } \\
\text { was reduced to } 40.8 \% \\
\text { after one day recovery }\end{array}$ & [112] \\
\hline $\begin{array}{l}\text { Actinidia } \\
\text { chinensis var. } \\
\text { deliciosa. }\end{array}$ & $\begin{array}{l}\text { 8wk-old in vitro } \\
\text { shoots derived } \\
\text { from } \\
\text { cryopreser-ved } \\
\text { apices, and } 3 \\
\text { mo-old ex vitro } \\
\text { plants }\end{array}$ & $\begin{array}{l}\text { Corresponding } \\
\text { in vitro-derived } \\
\text { samples }\end{array}$ & $\begin{array}{c}\text { Droplet- } \\
\text { vitrification }\end{array}$ & $\sqrt{ }$ ISSR, AFLP & $\begin{array}{c}\text { In vitro: } 22 \text { DNA de } \\
\text { novo methylation and } \\
30 \text { DNA } \\
\text { demethylation } \\
\text { markers out of } 718 \\
\text { Ex vitro: } 6 \text { DNA de } \\
\text { novo methylation and } \\
\text { one DNA } \\
\text { demethylation marker } \\
\text { out of } 701\end{array}$ & [111] \\
\hline
\end{tabular}

\section{Statistical Methods for MSAP Analysis in Plant Conservation}

A specific DNA methylation state reflects the outcome of the dynamic regulation of establishment, maintenance and removal activities: de novo methylation, maintenance of DNA methylation, active DNA methylation and passive DNA methylation $[113,114]$. These activities are catalyzed by several enzymes that act in a coordinate fashion and are activated by different mechanisms, making the level of DNA methylation in the cells dynamic and variable, and therefore affecting MSAP results analyses.

There are many factors that affect the level of methylation in CCGG sequences and that cause the number of fragments produced by the MSAP technique to vary from sample to sample. In ecological and population DNA methylation-related studies [39,115], where DNA samples are obtained from several individuals, there is variation in GC content and methylation level between those individuals. In these studies, it is important to consider that during the sampling process an additional statistical variation is generated due to the sampled individuals. In addition to the inter-individual variation in DNA methylation, there are variations in the levels of methylation between tissues of an organism because of differences in gene expression in the process of cell growth and differentiation [113]. 
There are many studies that relate the level of DNA methylation and abiotic and biotic factors both in plant physiology and in vitro culture $[89,112,116,117]$. In these cases, it is also important to consider the methylation variation caused during the experiment (stochastic variations). For this reason, it is appropriate to use multiple replicates in each experimental condition to determine if the observed differences are due to the factors investigated or we are simply detecting experimental variability.

Likewise, together with the biological variability in the methylation level of the samples, it must be taken into account that although the MSAP technique is quite reproducible, there may be technical errors that cause a fragment to be absent or present [118]. In this sense, some authors replicate independently some samples to be studied by the MSAP technique; they determine an error rate per fragment and only consider to analyze those fragments with error rates lower than a threshold value $[89,119,120]$. These authors report error rates ranging from $2 \%$ to $10 \%$. In this regard, Bonin et al. [118] indicated the possibility of developing statistical models that incorporate these errors and assess their impact on the final inference.

Therefore, the variation in the measured outcome detected in MSAP analysis is the cumulative effect of all these types of variation (i.e., genetic, environmental, and experimental variation) and any additional unexplained variation. These variations must be considered in the data analysis for a proper interpretation of the results (precision of the estimates, level of significance). Although in the particular case of in vitro culture studies genotype variation is usually not considered since samples are clones from a unique genotype, the rest of the causes still apply and may affect the degree of methylation and their subsequent detection.

In population genetic studies, the statistical techniques used are mainly multivariate methods. They calculate a similarity index between the experimental conditions (Jaccard, Nei, Dice index), and with these matrices they perform principal coordinate analysis (PCoA) and hierarchical classification with the unweighted pair-group method using arithmetic average algorithm (UPGMA) aimed at estimating the DNA methylation-related dissimilarities between populations. They usually carry out resampling methods (bootstrap, permutation) to obtain the precision of the estimates they produce.

Some studies on in vitro culture related to conservation procedures (slow growth and cryopreservation) do not report how many DNA samples from each experimental condition were used to perform the MSAP analysis. In some cases, a single sample was used per experimental condition, it being sometimes a pool of several samples [111,121-123]. Or the fragments obtained from the different analyzed samples were counted together without considering the variability between the samples within each experimental condition. It is also frequent to find comparisons among individuals or tissues of different developmental or physiological state, with a consequent misinterpretation of the results.

In most of these studies, only a description of methylation events and/or changes in methylation between different conditions was stated [111,121,122,124]. A statistical analysis of this type of samples would only reflect the variability between fragments for the different experimental conditions but does not allow to compare it with the experimental error.

When a statistical analysis was carried out, most of the published works used the multivariate techniques proposed in the studies of population epigenetics $[80,98,123]$. These methods are suitable in the context of population epigenetics, where a large number of individuals within the population are measured and the interest is to quantify diversity based on differences of DNA methylation markers between populations. However, in in vitro culture studies or experimental studies on the influence of abiotic or biotic stress on DNA methylation, the main interest is to show how and to what extent experimental conditions affect methylation and demethylation processes. To this end, some authors used ANOVA and the two-sample t-test in their studies to compare the percentages of the different methylation events that can be detected with the MSAP technique $[89,125]$. The drawback of these analyses is that they are assuming that the methylation events follow a normal distribution, which in the case of the presence/absence of fragments, may not be correct. 
Ibáñez et al. [112] developed an on-line application (Methylation Analysis Inference-MAI—application) to facilitate the statistical analysis of MSAP markers. This application uses the multinomial distribution to model the different methylation events detected with the MSAP technique. Although it can be used to analyze changes versus a control (unchanged, de novo methylation and demethylation), the approach is also valid for modeling events detected directly from MSAP markers (without a control), using the binomial distribution in the case of only two methylation events. This approach takes into account the variability between samples within each experimental condition. To achieve this, several biological replicates per experimental condition should be used, and each replication independently digested with MSAP enzymes provides a different fragment pattern in each sample. Statistical analysis separates experimental variability and determines if the differences detected could be due to changes in experimental conditions and not just a consequence of experimental variability. MAI application has been used to analyze MSAP data from cryopreserved apices [112] and stored seeds [58].

\section{Conclusions}

There are over five million accessions stored worldwide by different means, which play a crucial role in both food security and biodiversity maintenance. The different storage procedures (seed banking, in vitro and cryopreservation) impose stresses to plant cells that could cause several molecular alterations including epigenetic changes. Although still far from being a reality, it would be compelling and useful to find epigenetic changes associated to specific stresses imposed by storage conditions that could be used as biomarkers. Here, studies on DNA methylation variability occurring under storage condition have been reviewed. Demethylation events were the most frequently reported after storage. Although most of these changes are likely to be transient, some could be transferred to offspring. The level of DNA methylation changes detected in the different samples strongly differs resulting significantly high in some cases and quite low in others. That could be related to either a different capacity of different species to cope with stress imposed by storage conditions or to different storage conditions or sample stage. However, the different authors report their results in a non-homogeneous way, which makes it difficult to establish clear conclusions regarding the methylation changes occurring during ex situ conservation. In general, there are still many aspects to be clarified on the relationship between germplasm storage and DNA methylation. To this aim, MSAP is an easy-to-use technique that does not require previous knowledge of the species genome that could be used for screening DNA methylation variations occurring during storage. However, it must be considered that DNA methylation pattern not only differs between species but can also be stageand tissue-specific. As the main objective is to maintain the genetic and functional integrity of stored samples, comparisons with non-stored plant material (control) should be performed paying attention to compare samples at similar developmental stages. Therefore, the comparison of, or example, in vitro and ex vitro plants will, undoubtedly, result in differences in the epigenetic status (Figure 1). Nevertheless, an adequate design of the sampling and a sound statistical analysis are necessary to draw clear conclusions. Thus, the number of replicates should be high enough to account for stochastic variation. The use of appropriate statistical analysis will help to discern among stochastic and treatment-induced changes and will facilitate the development of more appropriate conservation methodologies [112].

Author Contributions: Conceptualization: C.M., M.A.I. and M.E.G.-B.; writing—original draft preparation, review and editing: C.M., M.Á.I., M.E.G.-B., M.P. and S.M. Funding acquisition: M.E.G.-B. All authors have read and agreed to the published version of the manuscript.

Funding: This research was funded by the project AGL2015-64899-C2-1-P (MINECO/FEDER), Spanish Government. M. Pirredda is supported by Programa Propio de I + D + I, Universidad Politécnica de Madrid.

Conflicts of Interest: The authors declare no conflict of interest. 


\section{Abbreviations}

$\begin{array}{ll}\text { AFLP } & \text { Amplified Fragment Length Polymorphism } \\ \text { AMP } & \text { Amplified DNA methylation polymorphism } \\ \text { CMT } & \text { Chromomethylase } \\ \text { DNMT } & \text { DNA Methyltransferases } \\ \text { DRM } & \text { Domains Rearranged Methyltransferase } \\ \text { fwb } & \text { Fresh weight basis } \\ \text { HPLC } & \text { high-performance liquid chromatography } \\ \text { ISSR } & \text { Inter Simple Sequence Repeat } \\ \text { LN } & \text { Liquid Nitrogen } \\ \text { MAI } & \text { Methylation Analysis Inference } \\ \text { MET } & \text { Methyltransferase } \\ \text { metAFLP } & \text { methylation-sensitive Amplified Fragment Length Polymorphism } \\ \text { MSAP } & \text { Methylation Sensitive Amplified Polymorphism } \\ \text { RAPD } & \text { Random Amplified Polymorphic DNA } \\ \text { RdDM } & \text { RNA-directed DNA methylation } \\ \text { ROS } & \text { Reactive Oxygen Species } \\ \text { SSR } & \text { Simple Sequence Repeat } \\ \text { TLC } & \text { Thin-layer chromatography } \\ \text { UPGMA } & \text { Unweighted pair group method with arithmetic mean } \\ \text { wc. } & \text { water content }\end{array}$

\section{References}

1. Corlett, R.T. A bigger toolbox: Biotechnology in biodiversity conservation. Trends Biotechnol. 2017, 35, 55-65. [CrossRef] [PubMed]

2. Coelho, N.; Gonçalves, S.; Romano, A. Endemic plant species conservation: Biotechnological approaches. Plants 2020, 9, 345. [CrossRef] [PubMed]

3. Fu, Y.-B. The vulnerability of plant genetic resources conserved ex situ. Crop Sci. 2017, 57, $2314-2328$. [CrossRef]

4. Buitink, J.; Leprince, O. Intracellular glasses and seed survival in the dry state. C. R. Biol. 2008, 331, 788-795. [CrossRef] [PubMed]

5. Zinsmeister, J.; Leprince, O.; Buitink, J. Molecular and environmental factors regulating seed longevity. Biochem. J. 2020, 477, 305-323. [CrossRef] [PubMed]

6. Wang, M.-R.; Lambardi, M.; Engelmann, F.; Pathirana, R.; Panis, B.; Volk, G.M.; Wang, Q.-C. Advances in cryopreservation of in vitro-derived propagules: Technologies and explant sources. Plant Cell Tissue Organ Cult. 2020. [CrossRef]

7. Gonzalez Benito, M.E.; Clavero-Ramírez, I.; López-Aranda, J.M. Review. The use of cryopreservation for germplasm conservation of vegetatively propagated crops. Span. J. Agric. Res. 2004, 2, 341-351. [CrossRef]

8. Flanagan, S.P.; Forester, B.R.; Latch, E.K.; Aitken, S.N.; Hoban, S. Guidelines for planning genomic assessment and monitoring of locally adaptive variation to inform species conservation. Evol. Appl. 2018, 11, 1035-1052. [CrossRef]

9. Eizaguirre, C.; Baltazar-Soares, M. Evolutionary conservation-evaluating the adaptive potential of species. Evol. Appl. 2014, 7, 963-967. [CrossRef]

10. Keller, T.E.; Lasky, J.R.; Yi, S.V. The multivariate association between genomewide DNA methylation and climate across the range of Arabidopsis thaliana. Mol. Ecol. 2016, 25, 1823-1837. [CrossRef]

11. Jeremias, G.; Barbosa, J.; Marques, S.M.; Asselman, J.; Gonçalves, F.J.M.; Pereira, J.L. Synthesizing the role of epigenetics in the response and adaptation of species to climate change in freshwater ecosystems. Mol. Ecol. 2018, 27, 2790-2806. [CrossRef]

12. Bender, J. DNA methylation and epigenetics. Annu. Rev. Plant Biol. 2004, 55, 41-68. [CrossRef] [PubMed]

13. Zhong, X. Comparative epigenomics: A powerful tool to understand the evolution of DNA methylation. New Phytol. 2016, 210, 76-80. [CrossRef] 
14. Pei, L.; Zhang, L.; Li, J.; Shen, C.; Qiu, P.; Tu, L.; Zhang, X.; Wang, M. Tracing the origin and evolution history of methylation-related genes in plants. BMC Plant Biol. 2019, 19, 307. [CrossRef] [PubMed]

15. Law, J.A.; Jacobsen, S.E. Establishing, maintaining and modifying DNA methylation patterns in plants and animals. Nat. Rev. Genet. 2010, 11, 204-220. [CrossRef] [PubMed]

16. Finnegan, E.; Peacock, W.; Dennis, E. DNA methylation, a key regulator of plant development and other processes. Curr. Opin. Genet. Dev. 2000, 10, 217-223. [CrossRef]

17. Martienssen, R.A.; Colot, V. DNA methylation and epigenetic inheritance in plants and filamentous fungi. Science 2001, 293, 1070-1074. [CrossRef]

18. Matzke, M.A.; Mosher, R.A. RNA-directed DNA methylation: An epigenetic pathway of increasing complexity. Nat. Rev. Genet. 2014, 15, 394-408. [CrossRef]

19. Rey, O.; Eizaguirre, C.; Angers, B.; Baltazar-Soares, M.; Sagonas, K.; Prunier, J.G.; Blanchet, S. Linking epigenetics and biological conservation: Towards a conservation epigenetics perspective. Funct. Ecol. 2020, 34, 414-427. [CrossRef]

20. Vogt, G. Facilitation of environmental adaptation and evolution by epigenetic phenotype variation: Insights from clonal, invasive, polyploid, and domesticated animals. Environ. Epigenet. 2017, 3. [CrossRef]

21. Feng, S.; Jacobsen, S.; Reik, W. Epigenetic reprogramming in plant and animal development. Science 2010, 330, 622-627. [CrossRef] [PubMed]

22. Quadrana, L.; Colot, V. Plant transgenerational epigenetics. Annu. Rev. Genet. 2016, 50, 467-491. [CrossRef] [PubMed]

23. Dubrovina, A.S.; Kiselev, K.V. Age-associated alterations in the somatic mutation and DNA methylation levels in plants. Plant Biol. 2016, 18, 185-196. [CrossRef] [PubMed]

24. Jiang, C.; Mithani, A.; Belfield, E.J.; Mott, R.; Hurst, L.D.; Harberd, N.P. Environmentally responsive genome-wide accumulation of de novo Arabidopsis thaliana mutations and epimutations. Genome Res. 2014, 24, 1821-1829. [CrossRef] [PubMed]

25. Verhoeven, K.J.F.; Preite, V. Epigenetic variation in asexually reproducing organisms. Evolution 2013, 68, 644-655. [CrossRef] [PubMed]

26. Yong, W.-S.; Hsu, F.-M.; Chen, P.-Y. Profiling genome-wide DNA methylation. Epigenet. Chromatin 2016, 9, 26. [CrossRef]

27. Suzuki, M.M.; Bird, A. DNA methylation landscapes: Provocative insights from epigenomics. Nat. Rev. Genet. 2008, 9, 465-476. [CrossRef]

28. Dahl, C.; Guldberg, P. DNA methylation analysis techniques. Biogerontology 2003, 4, 233-250. [CrossRef]

29. Grunau, C.; Clark, S.J.; Rosenthal, A. Bisulfite genomic sequencing: Systematic investigation of critical experimental parameters. Nucleic Acids Res. 2001, 29, e65. [CrossRef]

30. Reyna-López, G.E.; Simpson, J.; Ruiz-Herrera, J. Differences in DNA methylation patterns are detectable during the dimorphic transition of fungi by amplification of restriction polymorphisms. Mol. Gen. Genet. MGG 1997, 253, 703-710. [CrossRef]

31. Xiong, L.Z.; Xu, C.G.; Maroof, M.S.; Zhang, Q. Patterns of cytosine methylation in an elite rice hybrid and its parental lines, detected by a methylation-sensitive amplification polymorphism technique. Mol. Gen. Genet. MGG 1999, 261, 439-446. [CrossRef] [PubMed]

32. Portis, E.; Acquadro, A.; Comino, C.; Lanteri, S. Analysis of DNA methylation during germination of pepper (Capsicum annuиm L.) seeds using methylation-sensitive amplification polymorphism (MSAP). Plant Sci. 2004, 166, 169-178. [CrossRef]

33. Meng, F.R.; Li, Y.C.; Yin, J.; Liu, H.; Chen, X.J.; Ni, Z.F.; Sun, Q.X. Analysis of DNA methylation during the germination of wheat seeds. Biol. Plant. 2012, 56, 269-275. [CrossRef]

34. Rodriguez, M.P.; Cervigni, G.D.L.; Quarin, C.L.; Ortiz, J.P.A. Frequencies and variation in cytosine methylation patterns in diploid and tetraploid cytotypes of Paspalum notatum. Biol. Plant. 2012, 56, 276-282. [CrossRef]

35. Takata, M.; Kishima, Y.; Sano, Y. DNA Methylation polymorphisms in rice and wild rice strains: Detection of epigenetic markers. Breed. Sci. 2005, 55, 57-63. [CrossRef]

36. Wang, W.-S.; Pan, Y.-J.; Zhao, X.-Q.; Dwivedi, D.; Zhu, L.-H.; Ali, J.; Fu, B.-Y.; Li, Z.-K. Drought-induced site-specific DNA methylation and its association with drought tolerance in rice (Oryza sativa L.). J. Exp. Bot. 2011, 62, 1951-1960. [CrossRef]

37. Aina, R.; Sgorbati, S.; Santagostino, A.; Labra, M.; Ghiani, A.; Citterio, S. Specific hypomethylation of DNA is induced by heavy metals in white clover and industrial hemp. Physiol. Plant. 2004, 121, 472-480. [CrossRef] 
38. Greco, M.; Chiappetta, A.; Bruno, L.; Bitonti, M.B. Effects of light deficiency on genome methylation in Posidonia oceanica. Mar. Ecol. Prog. Ser. 2013, 473, 103-114. [CrossRef]

39. Schulz, B.; Eckstein, R.L.; Durka, W. Scoring and analysis of methylation-sensitive amplification polymorphisms for epigenetic population studies. Mol. Ecol. Resour. 2013, 13, 642-653. [CrossRef]

40. Fulnecek, J.; Kovarik, A. How to interpret methylation sensitive amplified polymorphism (MSAP) profiles? BMC Genet. 2014, 15, 2-9. [CrossRef]

41. Salmon, A.; Clotault, J.; Jenczewski, E.; Chable, V.; Manzanares-Dauleux, M.J. Brassica oleracea displays a high level of DNA methylation polymorphism. Plant Sci. 2008, 174, 61-70. [CrossRef]

42. Herrera, C.; Bazaga, P. Epigenetic differentiation and relationship to adaptive genetic divergence in discrete populations of the violet Viola cazorlensis. New Phytol. 2010, 187, 867-876. [CrossRef]

43. Richards, C.L.; Schrey, A.W.; Pigliucci, M. Invasion of diverse habitats by few Japanese knotweed genotypes is correlated with epigenetic differentiation. Ecol. Lett. 2012, 15, 1016-1025. [CrossRef]

44. REBASE. The Restriction Enzyme Database. Available online: http://rebase.neb.com/rebase/rebase.html (accessed on 7 August 2020).

45. Schrey, A.W.; Alvarez, M.; Foust, C.M.; Kilvitis, H.J.; Lee, J.D.; Liebl, A.L.; Martin, L.B.; Richards, C.L.; Robertson, M. Ecological epigenetics: Beyond MS-AFLP. Integr. Comp. Biol. 2013, 53, 340-350. [CrossRef]

46. Zhao, K.; Aranzana, M.J.; Kim, S.; Lister, C.; Shindo, C.; Tang, C.; Toomajian, C.; Zheng, H.; Dean, C.; Marjoram, P.; et al. An Arabidopsis example of association mapping in structured samples. PLoS Genet. 2007, 3, e4. [CrossRef]

47. Bednarek, P.T.; Orłowska, R.; Koebner, R.M.D.; Zimny, J. Quantification of the tissue-culture induced variation in barley (Hordeum vulgare L.). BMC PlantBiol. 2007, 7, 10. [CrossRef]

48. Fu, Y.-B.; Ahmed, Z.; Diederichsen, A. Towards a better monitoring of seed ageing under ex situ seed conservation. Conserv. Physiol. 2015, 3, cov026. [CrossRef]

49. WIEWS. World Information and Early Warning System on Plant Genetic Resources for Food and Agriculture. Available online: http://www.fao.org/wiews/en/ (accessed on 15 June 2020).

50. Kurek, K.; Plitta-Michalak, B.; Ratajczak, E. Reactive oxygen species as potential drivers of the seed aging process. Plants 2019, 8, 174. [CrossRef]

51. Roach, T.; Nagel, M.; Börner, A.; Eberle, C.; Kranner, I. Changes in tocochromanols and glutathione reveal differences in the mechanisms of seed ageing under seedbank conditions and controlled deterioration in barley. Environ. Exp. Bot. 2018, 156, 8-15. [CrossRef]

52. Rajjou, L.; Duval, M.; Gallardo, K.; Catusse, J.; Bally, J.; Job, C.; Job, D. Seed germination and vigor. Annu. Rev. Plant Biol. 2012, 63, 507-533. [CrossRef]

53. Halliwell, B.; Gutteridge, J.M.C. Free Radicals in Biology and Medicine, 5th ed.; Oxford University Press: New York, NY, USA, 2015; ISBN 978-0-19-180213-3.

54. Fleming, M.B.; Hill, L.M.; Walters, C. The kinetics of ageing in dry-stored seeds: A comparison of viability loss and RNA degradation in unique legacy seed collections. Ann. Bot. 2019, 123, 1133-1146. [CrossRef] [PubMed]

55. Streczynski, R.; Clark, H.; Whelehan, L.M.; Ang, S.-T.; Hardstaff, L.K.; Funnekotter, B.; Bunn, E.; Offord, C.A.; Sommerville, K.D.; Mancera, R.L. Current issues in plant cryopreservation and importance for ex situ conservation of threatened Australian native species. Aust. J. Bot. 2019, 67, 1-15. [CrossRef]

56. Tsikas, D. Assessment of lipid peroxidation by measuring malondialdehyde (MDA) and relatives in biological samples: Analytical and biological challenges. Anal. Biochem. 2017, 524, 13-30. [CrossRef] [PubMed]

57. Ahmed, Z.; Shah, Z.H.; Rehman, H.M.; Shahzad, K.; Daur, I.; Elfeel, A.; Hassan, M.U.; Elsafori, A.K.; Yang, S.H.; Chung, G. Genomics: A hallmark to monitor molecular and biochemical processes leading toward a better perceptive of seed aging and ex-situ conservation. Curr. Issues Mol. Biol. 2017, 89-112. [CrossRef] [PubMed]

58. Pirredda, M.; González-Benito, M.E.; Martín, C.; Mira, S. Genetic and epigenetic stability in rye seeds under different storage conditions: Ageing and oxygen effect. Plants 2020, 9, 393. [CrossRef]

59. Mira, S.; Pirredda, M.; Martín-Sánchez, M.; Marchessi, J.E.; Martín, C. DNA methylation and integrity in aged seeds and regenerated plants. Seed Sci. Res. 2020, 1-9. [CrossRef]

60. Barciszewska, M.Z.; Barciszewska, A.M.; Rattan, S.I.S. TLC-based detection of methylated cytosine: Application to aging epigenetics. Biogerontology 2007, 8, 673-678. [CrossRef] [PubMed] 
61. Guzy-Wrobelska, J.; Filek, M.; Kaliciak, A.; Szarejko, I.; Macháčková, I.; Krekule, J.; Barciszewska, M. Vernalization and photoperiod-related changes in the DNA methylation state in winter and spring rapeseed. Acta Physiol. Plant 2013, 35, 817-827. [CrossRef]

62. Michalak, M.; Barciszewska, M.Z.; Barciszewski, J.; Plitta, B.P.; Chmielarz, P. Global changes in DNA methylation in seeds and seedlings of Pyrus communis after seed desiccation and storage. PLoS ONE 2013, 8 , e70693. [CrossRef]

63. Plitta, B.P.; Michalak, M.; Bujarska-Borkowska, B.; Barciszewska, M.Z.; Barciszewski, J.; Chmielarz, P. Effect of desiccation on the dynamics of genome-wide DNA methylation in orthodox seeds of Acer platanoides L. Plant Physiol. Biochem. 2014, 85, 71-77. [CrossRef]

64. Plitta-Michalak, B.P.; Naskręt-Barciszewska, M.Z.; Kotlarski, S.; Tomaszewski, D.; Tylkowski, T.; Barciszewski, J.; Chmielarz, P.; Michalak, M. Changes in genomic 5-methylcytosine level mirror the response of orthodox (Acer platanoides L.) and recalcitrant (Acer pseudoplatanus L.) seeds to severe desiccation. Tree Physiol. 2018, 38, 617-629. [CrossRef]

65. Pérez, J.; Araya-Valverde, E.; Garro-Monge, G.; Abdelnour-Esquivel, A. Analysis of stress indicators during cryopreservation of seeds of landrace maize (Zea mays). CryoLetters 2017, 38, 445-454.

66. Lu, J.; Greene, S.; Reid, S.; Cruz, V.M.V.; Dierig, D.A.; Byrne, P. Phenotypic changes and DNA methylation status in cryopreserved seeds of rye (Secale cereale L.). Cryobiology 2018, 82, 8-14. [CrossRef]

67. Engelmann, F. Use of biotechnologies for the conservation of plant biodiversity. Vitro Cell. Dev. Biol. Plant 2011, 47, 5-16. [CrossRef]

68. Ashmore, S.E. Status Report on the Development and Application of In Vitro Techniques for The Conservation and Use of Plant Genetic Resources; International Plant Genetics Research Institute: Rome, Italy, 1997; ISBN 978-92-9043-339-2.

69. Reed, B.M.; Engelmann, F.; Dulloo, M.E.; Engels, J.M. Technical Guidelines for the Management of Field and In Vitro Germplasm Collections; International Plant Genetic Resources Institute: Rome, Italy, 2004; ISBN 978-92-9043-640-9.

70. Da Silva, D.P.C.; Ozudogru, E.A.; Dos Reis, M.V.; Lambardi, M. In vitro conservation of ornamental plants. Ornam. Hortic. 2018, 24, 28-33. [CrossRef]

71. Sarasan, V.; Cripps, R.; Ramsay, M.M.; Atherton, C.; McMichen, M.; Prendergast, G.; Rowntree, J.K. Conservation in vitro of threatened plants-Progress in the past decade. Vitro Cell. Dev. Biol. Plant 2006, 42, 206-214. [CrossRef]

72. Bednarek, P.T.; Orłowska, R. Plant tissue culture environment as a switch-key of (epi)genetic changes. Plant Cell Tissue Organ Cult. 2020, 140, 245-257. [CrossRef]

73. Azizi, P.; Hanafi, M.M.; Sahebi, M.; Harikrishna, J.A.; Taheri, S.; Yassoralipour, A.; Nasehi, A. Epigenetic changes and their relationship to somaclonal variation: A need to monitor the micropropagation of plantation crops. Funct. Plant Biol. 2020, 47, 508-523. [CrossRef]

74. Lázaro-Castellanos, J.O.; Mata-Rosas, M.; González, D.; Arias, S.; Reverchon, F. In vitro propagation of endangered Mammillaria genus (Cactaceae) species and genetic stability assessment using SSR markers. Vitro Cell. Dev. Biol. Plant 2018, 54, 518-529. [CrossRef]

75. Hammond Hammond, S.D.; Viehmannova, I.; Zamecnik, J.; Panis, B.; Cepkova, P.H. Efficient slow-growth conservation and assessment of clonal fidelity of Ullucus tuberosus Caldas microshoots. Plant Cell Tissue Organ Cult. 2019, 138, 559-570. [CrossRef]

76. Samarina, L.; Gvasaliya, M.; Koninskaya, N.; Rakhmangulov, R.; Efremov, A.; Kiselyova, N.; Ryndin, A.; Hanke, M.-V. A comparison of genetic stability in tea [Camellia sinensis (L.) Kuntze] plantlets derived from callus with plantlets from long-term in vitro propagation. Plant Cell Tissue Organ Cult. 2019, 138, 467-474. [CrossRef]

77. Harding, K. The methylation status of DNA derived from potato plants recovered from slow growth. Plant Cell Tissue Organ Cult. 1994, 37, 31-38. [CrossRef]

78. Hao, Y.-J.; Deng, X. Genetically stable regeneration of apple plants from slow growth. Plant Cell Tissue Organ Cult. 2003, 72, 253-260. [CrossRef]

79. Hao, Y.-J.; Wen, X.-P.; Deng, X. Genetic and epigenetic evaluations of citrus calluses recovered from slow-growth culture. J. Plant Physiol. 2004, 161, 479-484. [CrossRef]

80. Peredo, E.L.; Arroyo-García, R.; Reed, B.M.; Revilla, M.A. Genetic and epigenetic stability of cryopreserved and cold-stored hops (Humulus lupulus L.). Cryobiology 2008, 57, 234-241. [CrossRef] 
81. Peredo, E.L.; Arroyo-García, R.; Reed, B.M.; Revilla, M.A. Genetic stability of in vitro conserved germplasm of Humulus lupulus L. Agric. Food Sci. 2009, 18, 144-151. [CrossRef]

82. Kundu, S.; Salma, U.; Ali, M.N.; Mandal, N. Conservation, ex vitro direct regeneration, and genetic uniformity assessment of alginate-encapsulated nodal cuttings of Sphagneticola calendulacea (L.) Pruski. Acta Physiol. Plant. 2018, 40, 53. [CrossRef]

83. Arumugam, G.; Sinniah, U.R.; Swamy, M.K.; Lynch, P.T. Encapsulation of in vitro Plectranthus amboinicus (Lour.) Spreng. shoot apices for propagation and conservation. 3 Biotech 2019, 9, 298. [CrossRef]

84. Kikowska, M.; Sliwinska, E.; Thiem, B. Micropropagation and production of somatic seeds for short-term storage of the endangered species Eryngium alpinum L. Plants 2020, 9, 498. [CrossRef]

85. Tavazza, R.; Rey, N.A.; Papacchioli, V.; Pagnotta, M.A. A validated slow-growth in vitro conservation protocol for globe artichoke germplasm: A cost-effective tool to preserve from wild to elite genotypes. Sci. Hortic. 2015, 197, 135-143. [CrossRef]

86. Koeda, S.; Matsumoto, S.; Matsumoto, Y.; Takisawa, R.; Nishikawa, K.; Kataoka, K. Medium-term in vitro conservation of virus-free parthenocarpic tomato plants. Vitro Cell. Dev. Biol. Plant 2018, 54, 392-398. [CrossRef]

87. Kamińska, M.; Gołębiewski, M.; Tretyn, A.; Trejgell, A. Efficient long-term conservation of Taraxacum pieninicum synthetic seeds in slow growth conditions. Plant Cell Tissue Organ Cult. 2018, 132, 469-478. [CrossRef]

88. Kaeppler, S.M.; Kaeppler, H.F.; Rhee, Y. Epigenetic aspects of somaclonal variation in plants. Plant Mol. Biol. 2000, 43, 179-188. [CrossRef] [PubMed]

89. Gimenez, M.D.; Yañez-Santos, A.M.; Paz, R.C.; Quiroga, M.P.; Marfil, C.F.; Conci, V.C.; García-Lampasona, S.C. Assessment of genetic and epigenetic changes in virus-free garlic (Allium sativum L.) plants obtained by meristem culture followed by in vitro propagation. Plant Cell Rep. 2016, 35, 129-141. [CrossRef] [PubMed]

90. Normah, M.N.; Sulong, N.; Reed, B.M. Cryopreservation of shoot tips of recalcitrant and tropical species: Advances and strategies. Cryobiology 2019, 87, 1-14. [CrossRef] [PubMed]

91. Höfer, M.; Hanke, M.-V. Cryopreservation of fruit germplasm. Vitro Cell. Dev. Biol. Plant 2017, 53, $372-381$. [CrossRef]

92. Niino, T.; Valle Arizaga, M. Cryopreservation for preservation of potato genetic resources. Breed. Sci. 2015, 65, 41-52. [CrossRef]

93. Popova, E.; Shukla, M.; Kim, H.H.; Saxena, P.K. Plant cryopreservation for biotechnology and breeding. In Advances in Plant Breeding Strategies: Breeding, Biotechnology and Molecular Tools; Al-Khayri, J.M., Jain, S.M., Johnson, D.V., Eds.; Springer: New York, NY, USA, 2015; pp. 63-93, ISBN 978-3-319-22521-0.

94. Reed, B.M. Plant Cryopreservation: A Practical Guide; Reed, B.M., Ed.; Springer: New York, NY, USA, 2008; ISBN 978-0-387-72275-7.

95. Kaczmarczyk, A.; Funnekotter, B.; Menon, A.; Phang, P.; Al-Hanbali, A.; Bunn, E.; Mancera, R.L. Current issues in plant cryopreservation. In Current Frontiers in Cryobiology; Katkov, I.I., Ed.; IntechOpen Ltd.: London, UK, 2012; pp. 417-438, ISBN 978-953-51-0191-8.

96. Benson, E.E.; Bremner, D. Oxidative stress in the frozen plant: A free radical point of view. In Life in the Frozen State; Fuller, B.J., Lan, N., Benson, E.E., Eds.; CRC Press: Boca Raton, FL, USA, 2004; pp. 205-242, ISBN 978-0-429-21248-2.

97. Uchendu, E.E.; Leonard, S.W.; Traber, M.G.; Reed, B.M. Vitamins C and E improve regrowth and reduce lipid peroxidation of blackberry shoot tips following cryopreservation. Plant Cell Rep. 2010, 29, 25-35. [CrossRef]

98. Adu-Gyamfi, R.; Wetten, A.; Rodríguez López, C.M. Effect of cryopreservation and post-cryopreservation somatic embryogenesis on the epigenetic fidelity of cocoa (Theobroma cacao L.). PLoS ONE 2016, 11, e0158857. [CrossRef]

99. Chatterjee, A.; Saha, D.; Niemann, H.; Gryshkov, O.; Glasmacher, B.; Hofmann, N. Effects of cryopreservation on the epigenetic profile of cells. Cryobiology 2017, 74, 1-7. [CrossRef]

100. Funnekotter, B.; Mancera, R.L.; Bunn, E. Advances in understanding the fundamental aspects required for successful cryopreservation of Australian flora. Vitro Cell. Dev. Biol. Plant 2017, 53, 289-298. [CrossRef]

101. Matsumoto, T. Cryopreservation of plant genetic resources: Conventional and new methods. Rev. Agric. Sci. 2017, 5, 13-20. [CrossRef]

102. Li, J.-W.; Ozudogru, E.A.; Li, J.; Wang, M.-R.; Bi, W.-L.; Lambardi, M.; Wang, Q.-C. Cryobiotechnology of forest trees: Recent advances and future prospects. Biodivers. Conserv. 2018, 27, 795-814. [CrossRef] 
103. Kaity, A.; Drew, R.A.; Ashmore, S.E. Genetic and epigenetic integrity assessment of acclimatised papaya plants regenerated directly from shoot-tips following short- and long-term cryopreservation. Plant Cell Tissue Organ Cult. 2013, 112, 75-86. [CrossRef]

104. Mikuła, A.; Tomiczak, K.; Rybczyński, J.J. Cryopreservation enhances embryogenic capacity of Gentiana cruciata (L.) suspension culture and maintains (epi)genetic uniformity of regenerants. Plant Cell Rep. 2011, 30, 565-574. [CrossRef]

105. Johnston, J.W.; Benson, E.E.; Harding, K. Cryopreservation induces temporal DNA methylation epigenetic changes and differential transcriptional activity in Ribes germplasm. Plant Physiol. Biochem. 2009, 47, 123-131. [CrossRef]

106. Hao, Y.-J.; Liu, Q.-L.; Deng, X.-X. Effect of cryopreservation on apple genetic resources at morphological, chromosomal, and molecular levels. Cryobiology 2001, 43, 46-53. [CrossRef]

107. Osorio-Montalvo, P.; Sáenz-Carbonell, L.; De-la-Peña, C. 5-Azacytidine: A promoter of epigenetic changes in the quest to improve plant somatic embryogenesis. Int. J. Mol. Sci. 2018, 19, 3182. [CrossRef]

108. Hao, Y.-J.; You, C.-X.; Deng, X.-X. Analysis of ploidy and the patterns of amplified fragment length polymorphism and methylation sensitive amplified polymorphism in strawberry plants recovered from cryopreservation. CryoLetters 2002, 23, 37-46.

109. Hao, Y.-J.; You, C.-X.; Deng, X.-X. Effects of cryopreservation on developmental competency, cytological and molecular stability of citrus callus. CryoLetters 2002, 23, 27-35.

110. Kaczmarczyk, A.; Houben, A.; Keller, E.R.J.; Mette, M.F. Influence of cryopreservation on the cytosine methylation state of potato genomic DNA. CryoLetters 2010, 31, 380-391. [PubMed]

111. Zhang, X.-C.; Bao, W.-W.; Zhang, A.; Pathirana, R.; Wang, Q.-C.; Liu, Z.-D. Cryopreservation of shoot tips, evaluations of vegetative growth, and assessments of genetic and epigenetic changes in cryo-derived plants of Actinidia spp. Cryobiology 2020, 94, 18-25. [CrossRef] [PubMed]

112. Ibáñez, M.A.; Alvarez-Mari, A.; Rodríguez-Sanz, H.; Kremer, C.; González-Benito, M.E.; Martín, C. Genetic and epigenetic stability of recovered mint apices after several steps of a cryopreservation protocol by encapsulation-dehydration. A new approach for epigenetic analysis. Plant Physiol. Biochem. 2019, 143, 299-307. [CrossRef] [PubMed]

113. Zhang, H.; Lang, Z.; Zhu, J.-K. Dynamics and function of DNA methylation in plants. Nat. Rev. Mol. Cell Biol. 2018, 19, 489-506. [CrossRef] [PubMed]

114. Sanchez-Muñoz, R.; Moyano, E.; Khojasteh, A.; Bonfill, M.; Cusido, R.M.; Palazon, J. Genomic methylation in plant cell cultures: A barrier to the development of commercial long-term biofactories. Eng. Life Sci. 2019, 19, 872-879. [CrossRef] [PubMed]

115. Lele, L.; Ning, D.; Cuiping, P.; Xiao, G.; Weihua, G. Genetic and epigenetic variations associated with adaptation to heterogeneous habitat conditions in a deciduous shrub. Ecol. Evol. 2018, 8, 2594-2606. [CrossRef] [PubMed]

116. Rodrigo, J.M.; Zappacosta, D.C.; Selva, J.P.; Garbus, I.; Albertini, E.; Echenique, V. Apomixis frequency under stress conditions in weeping lovegrass (Eragrostis curvula). PLoS ONE 2017, 12, e0175852. [CrossRef]

117. Liu, Z.-Z.; Chen, T.; Peng, F.-R.; Liang, Y.-W.; Tan, P.-P.; Mo, Z.-H.; Cao, F.; Shang, Y.-J.; Zhang, R.; Li, Y.-R. Variation in cytosine methylation among pecan cultivars at different developmental stages. J. Am. Soc. Hortic. Sci. 2018, 143, 173-183. [CrossRef]

118. Bonin, A.; Bellemain, E.; BronkenEidesen, P.; Pompanon, F.; Brochmann, C.; Taberlet, P. How to track and assess genotyping errors in population genetics studies: Tracking and assessing genotyping errors. Mol. Ecol. 2004, 13, 3261-3273. [CrossRef]

119. Alsdurf, J.; Anderson, C.; Siemens, D.H. Epigenetics of drought-induced trans-generational plasticity: Consequences for range limit development. AoB Plants 2016, 8, plv146. [CrossRef]

120. Alonso, C.; Pérez, R.; Bazaga, P.; Medrano, M.; Herrera, C.M. MSAP markers and global cytosine methylation in plants: A literature survey and comparative analysis for a wild-growing species. Mol. Ecol. Resour. 2016, 16, 80-90. [CrossRef] [PubMed]

121. Ran, L.; Li, M.; Fan, H.X.; Jiang, J.J.; Wang, Y.P.; Sokolov, V. Epigenetic variation in the callus of Brassica napus under different inducement conditions. Russ. J. Genet. 2016, 52, 802-809. [CrossRef]

122. Goyali, J.C.; Igamberdiev, A.U.; Debnath, S.C. DNA methylation in lowbush blueberry (Vaccinium angustifolium Ait.) propagated by softwood cutting and tissue culture. Can. J. Plant Sci. 2018, 98, 1035-1044. [CrossRef] 
123. Jekayinoluwa, T.; Gueye, B.; Bhattacharjee, R.; Osibanjo, O.; Shah, T.; Abberton, M. Agromorphologic, genetic and methylation profiling of Dioscorea and Musa species multiplied under three micropropagation systems. PLoS ONE 2019, 14, e0216717. [CrossRef] [PubMed]

124. Ghosh, A.; Igamberdiev, A.U.; Debnath, S.C. Detection of DNA methylation pattern in thidiazuron-induced blueberry callus using methylation-sensitive amplification polymorphism. Biol. Plant. 2017, 61, 511-519. [CrossRef]

125. Bobadilla Landey, R.; Cenci, A.; Guyot, R.; Bertrand, B.; Georget, F.; Dechamp, E.; Herrera, J.-C.; Aribi, J.; Lashermes, P.; Etienne, H. Assessment of genetic and epigenetic changes during cell culture ageing and relations with somaclonal variation in Coffea arabica. Plant Cell Tissue Organ Cult. 2015, 122, 517-531. [CrossRef]

(C) 2020 by the authors. Licensee MDPI, Basel, Switzerland. This article is an open access article distributed under the terms and conditions of the Creative Commons Attribution (CC BY) license (http://creativecommons.org/licenses/by/4.0/). 